\title{
Hyper-Transaminasemia During Curative Treatment Based On Artemisinine Derivatives
}

\author{
Djenebou Traoré ${ }^{*}$, Djeneba Sylla Sow ${ }^{2}$, Djibril Sy ${ }^{1}$, Abdoulaye Mamadou Traoré ${ }^{3}$, Assétou Kaya Soukho ${ }^{1}$, Abdel \\ Kader Traoré ${ }^{1}$, Mamadou Dembele ${ }^{1}$, Assa Traore Sidibé2 and Hamar Alassane Traoré ${ }^{1}$
}

${ }^{1}$ Department of Internal Medicine, Point G Hospital Unit, Mali

${ }^{2}$ Department of Internal Medicine and Endocrinology, Mali Hospital, Mali

${ }^{3}$ Department of Infectious Disease, Point G Hospital Unit, Mali

Submission: September 16, 2019; Published: September 24, 2019

*Corresponding author: Djénébou Traoré, Department of Internal Medicine and Endocrinology of the Mali Hospital, Mali

\section{Abstract}

The extension of chloroquine resistance to most African countries in 2002 led the World Health Organization (WHO) to recommend firstline treatment of uncomplicated malaria by artemisinin-based combinations.

Observation: Mrs. A. C, aged 26, of Malian origin, mother of 3 children, housewife without pathological history, did not usually take any medicine and was not pregnant. In November 2014, consults for asthenia, headache, fever, vertigo for 24 hours; where a combination therapy with artemether-lumefantrine was prescribed after investigation of Plasmodium at the thick-leaved (GE) site with parasitemia at 350/field. Its evolution was marked by the occurrence of hyper transaminase at more than 5 times normal following a treatment of malaria associated with dyspnea, tinnitus, oliguria with edema of the lower limbs and ascites. Serologies of hepatitis A, B, C and HIV negative.

Conclusion: This observation obliges us to be doubly vigilant and to report all observed accidents in order to feed and document the pharmacovigilance databases.

Keywords: Hyper transaminase; Artemisinin; Mali hospital

Abbreviations: ALT: Alanine Amino Transferase; AST: Aspartate Amino Transferase; SGOT: Glutamate-Oxaloacetate Transferase Serum; ASAT: Aspartate-Amino-Transferase

\section{Introduction}

Hyper transaminase is defined as elevation of serum ALT (Alanine Amino Transferase) and / or AST (Aspartate Amino Transferase) greater than one and a half times normal. Transaminases are two enzymes that transfer amino groups from two amino acids including alanine and aspartic acid to form two others (pyruvic acid and ovalocyte acid): Alanine Aminotransferase (ALT), formerly known as Glutamic Pyruvic Transferase Serum (SGPT), is of essentially hepatic and accessory muscular origin.

Aspartate Amino Transferase (ASAT), formerly known as Glutamate-Oxaloacetate Transferase Serum (SGOT), is found in the myocardium, muscles, kidneys, brain and liver [1].

\section{Observation}

The authors report their experience. This is a patient named Mrs. A. Coulibaly, aged 26 married in a polygamous regime, of
Malian origin. She is the mother of 3 children, housewife with no known pathological history or previous drug intake and was not pregnant.

In November 2014, she consulted for asthenia, headache, fever, vertigo for 24 hours; where a combination therapy with artemether-lumefantrine was prescribed after investigation of Plasmodium at the thick-leaved (GE) site with parasitemia at 350 / field.

At four days of this treatment, she consults for intense asthenia, chills, pruritus, anorexia with biology always positive GE at 150 / field, Aspartate-amino-transferase (ASAT) = 85 IU / l, Alanine aminotransferase $($ ALT $)=63 \mathrm{IU} / \mathrm{l}$, Prothrombin Ratio (PT) 119\%. A treatment was instituted based on intramuscular artemether injection for a 5-day protocol.

At two days of this protocol, the patient presents with jaundice, with hyper transaminase at more than 5 times normal 
(ASAT = $252 \mathrm{IU} / \mathrm{l}$, ALAT = $224 \mathrm{IU} / \mathrm{l})$ while dyspnea, buzzing an oliguria with edema of the lower limbs and ascites. Serologies of hepatitis A, B, C and HIV were negative.

\section{Discussion}

When a patient consults in the emergency room for abnormalities of the liver biological balance, two different situations must be distinguished, even if the initial presentation may be close. Either the patient with an old hepatopathy, most often known, or it is about acute abnormalities occurring on a previously healthy liver. Only the second situation is envisaged in this text. In the case of recent abnormalities in previously healthy liver, these biological abnormalities should be characterized, and the accompanying clinical elements should be assessed, in particular the existence of abdominal pains and fever. Schematically, the emergency physician must distinguish [2]. Acute cytolysis, dominated by acute hepatitis whose problem is to determine the cause and severity, Cholestasis, moderate cytolysis (transaminases $<10 \mathrm{~N}$ ) or mixed abnormalities whose problem in emergency consultation is primarily to eliminate complicated biliary diseases.

The degree of elevation of transaminases may allow us to make an etiological research. Significant hyper transaminase is an elevation of serum ASAT and / or ALAT greater than ten times the upper limit of normal.

The height of the elevation peak of hyper transaminase is not generally correlated with the extent of liver damage. It is rather the brutal and massive character of the aggression of the liver that explains the height of the sometimes-elevated peak of elevation of transaminases by:

This work is licensed under Creative Commons Attribution 4.0 License DOI: 10.19080/JOJCS.2019.10.555792 a) A virus: acute viral hepatitis.

b) An ischemic injury a toxic (alcohol, halothane, paracetamol, tetra carbon chloride, phalloidin amanita toxin) $[2,3]$.

With a moderate elevation of transaminases, pre-existing liver disease may be considered. In the majority of cases, chronic liver disease is accompanied by a moderate increase in serum transaminase activity (greater than 1.5 normal and less than 10 times normal). The increase in transaminases is often a corollary of a disruption of cholestane enzymes (gamma -GT, alkaline phosphatase); only conditions where hyper transaminase predominates will be discussed here.

Diseases specific to hepatic parenchyma (and bile ducts) and manifestations related to the repercussions on liver function of an extra-hepatic disease can be distinguished. Biopsy of the liver, trans venous if there are disorders of coagulation, can sometimes guide the investigations [3].

\section{Conclusion}

This observation obliges us to be doubly vigilant and to report all observed accidents in order to feed and document the pharmacovigilance databases.

\section{References}

1. Godeau P, Herson S, Charles Piette J (1992) Acute hepatitis drug, acute toxic hepatitis, alcoholic hepatitis. In Internal Medicine 288: 1164 $-1166$.

2. Pateron D, Legendre N, Debuc E (2009) Liver abnormalities to emergencies. Emergency 40: 435-445.

3. Daniel SP, Marshall MK (2000) Evaluation of abnormal liver-enzyme results in symptomatic patients. N Engl J Med 342(17): 1266-1271.

\section{Your next submission with Juniper Publishers will reach you the below assets}

- Quality Editorial service

- Swift Peer Review

- Reprints availability

- E-prints Service

- Manuscript Podcast for convenient understanding

- Global attainment for your research

- Manuscript accessibility in different formats

( Pdf, E-pub, Full Text, Audio)

- Unceasing customer service

Track the below URL for one-step submission https://juniperpublishers.com/online-submission.php 